\title{
Pengaruh Kompetensi, Motivasi dan Disiplin Kerja terhadap Kinerja Pegawai Dinas Pendidikan Kota Makassar
}

\author{
Najdah Thalib1, Basri Modding2, Rastina Kalla ${ }^{3}$ \\ 12,3, Magister Manajemen, Universitas Muslim Indonesia. \\ ${ }^{1}$ Koresponden Penulis, E-mail: najdahthalib@gmail.com
}

\begin{abstract}
ABSTRAK
Penelitian ini bertujuan: 1) Untuk menganalisis seberapa besar pengaruh kompetensi, motivasi, dan disiplin kerja terhadap kinerja pegawai Dinas Pendidikan Kota Makassar; 2) Untuk menganalisis seberapa besar pengaruh kompetensi terhadap kinerja pegawai; 3) Untuk menganalisis seberapa besar pengaruh motivasi terhadap kinerja pegawai Dinas Pendidikan Kota Makassar; 4) Untuk menganalisis seberapa besar pengaruh disiplin kerja terhadap kinerja pegawai ; dan 5) Diantara variabel kompetensi, motivasi, dan disiplin kerja, variabel manakah yang lebih dominan berpengaruh terhadap kinerja pegawai Dinas Pendidikan Kota Makassar. Data yang digunakan adalah data primer dan data sekunder. Populasi dalam penelitian adalah seluruh pegawai Dinas Pendidikan Kota Makassar yang berjumlah 157 orang pegawai dari lima bidang. Dengan menggunakan probability sampling, peneliti menggunakan sampel acak sederhana atau simple random sampling sehingga diperoleh sampel yakni 24 orang atau 15\% dari populasi. Hasil penelitian menunjukkan bahwa: 1) Kompetensi, motivasi dan disiplin kerja bersama-sama mempunyai pengaruh positif dan signifikan terhadap kinerja pegawai Dinas Pendidikan Kota Makassar; 2) Kompetensi berpengaruh positif dan signifikan terhadap kinerja pegawai; 3) Motivasi berpengaruh positif dan signifikan terhadap kinerja pegawai; 4) Disiplin kerja berpengaruh positif dan signifikan terhadap kinerja pegawai; dan 5) Variabel disipilin kerja merupakan variabel yang paling dominan mempengaruhi kinerja pegawai jika dibandingkan dengan variabel motivasi dan kompetensi pada Dinas Pendidikan Kota Makassar.
\end{abstract}

Kata Kunci: Kompetensi, Motivasi, Disiplin Kerja, Kinerja Pegawai

\begin{abstract}
This study aims: 1) To analyze how much the influence of competence, motivation, and work discipline on the performance of Education Department employees of Makassar City; 2) To analyze how much the influence of competence on the employee performance; 3) To analyze how much the influence of motivation on the employee performance; 4) To analyze how much the influence of work discipline on the employee performance; and 5) Among the variables of competence, motivation, and work discipline, which variable is more dominant in influencing the performance of Education Department employees of Makassar City. The data used are primary data and secondary data. The population in this study were all employees of Education Department of Makassar, with the total number 157 employees from five fields. By using probability sampling, the researcher used simple random sampling to obtain a sample of 24 people or $15 \%$ of the population. The findings show that: 1) Competence, motivation, and work discipline together have a positive and significant effect on the performance of Education Department employees of Makassar City; 2) Competence has a positive and significant effect on the employee performance; 3) Motivation has a positive and significant effect on the employee performance; 4) Work discipline has a positive and significant effect on the employee performance; and 5) Work discipline is the most dominant variable affecting employee performance when compared to the motivation and competence variables of Makassar City Education Department.
\end{abstract}

Keywords: Competence, Motivation, Work Discipline, Employee Performance 


\section{PENDAHULUAN}

Dinas Pendidikan Kota Makassar merupakan komponen pemerintah daerah yang memiliki posisi strategis dalam memberikan pelayanan pendidikan kepada masyarakat yang senantiasa diperhadapkan pada tuntutan-tuntuan dari masyarakat akan pelayanan yang berkualitas, efisien, dan efektif. Mengacu kepada peraturan daerah Kota Makassar Nomor 17 Tahun 2005 tentang pembentukan, susunan organisasi dan tata kerja Dinas Pendidikan Kota Makassar, disebutkan bahwa Dinas Pendidikan Kota Makassar merupakan unsur pelaksana pemerintah kota yang dipimpin oleh seorang kepala yang berada di bawah dan bertanggung jawab kepada walikota melalui sekertaris daerah. Tugas pokok Dinas Pendidikan Kota Makassar adalah merumuskan, membina, dan mengendalikan kebijakan di bidang pendidikan yang meliputi pra sekolah, pendidikan dasar, pendidikan menengah, pendidikan luar sekolah, pemuda dan olahraga dan prasarana.

Sebagai pemangku kebijakan, sistem pengukuran kinerja dalam pendidikan sangat diperlukan. Sistem pengukuran kinerja dibangun dan dikembangkan untuk menilai sejauh mana capaian kinerja yang berhasil diperoleh. Pada setiap akhir periode pelaksanaan program/kegiatan, capaian kinerja yang berhasil diperoleh itu dikomunikasikan kepada para stakeholder dalam wujud laporan akuntabilitas kinerja. Laporan akuntabilitas kinerja memiliki dua fungsi utama; sebagai sarana menyampaikan pertanggungjawaban kinerja kepada Gubernur, DPRD dan masyarakat, dan sebagai sarana evaluasi atas pencapaian kinerja sebagai upaya untuk memperbaiki kinerja di masa mendatang. Menurut (Ruky, 2006), kinerja adalah catatan tentang hasil-hasil yang diperoleh dari fungsi-fungsi pekerjaan tertentu atau kegiatan tertentu selama kurun waktu tertentu. Dinas Pendidikan Kota Makassar telah melaksanakan berbagai program dan kegiatan dalam rangka peningkatan kualitas pendidikan. Capaian hasil atas pelaksanaan program strategis ini adalah indikator kinerja yang digunakan untuk mengukur capaian program dengan rincian yang dituangkan dalam laporan akuntabilitas Dinas Pendidikan Kota Makassar Tahun 2019.

Melihat hasil kinerja dinas pendidikan Kota Makassar melalui indikator kinerja sesuai dengan LAKIP (Laporan Akuntabilitas Kinerja Instansi Publik) Dinas Pendidikan Kota Makassar, menunjukkan bahwa dari 25 Indikator Kinerja Dinas Pendidikan Kota Makassar pada tahun 2019, 12 indikator menunjukkan capaian $100 \%$ atau lebih dan 23 indikator yang belum mencapai 100\% pada tahun 2019. Hal ini perlu mendapat perhatian yang penting dan perlu untuk lebih diupayakan lagi melalui peningkatan kinerja sesuai dengan kebijakan yang telah disusun. Masih diperlukan upaya kinerja yang lebih keras, fokus dan terarah dengan pertimbangan sejumlah analisa yang mempengaruhi.

Kinerja merupakan hal yang perlu diperhatikan dalam keefektifan organisasi. Kinerja merupakan hasil kerja yang secara kualitas dan kuantitas dicapai oleh seorang pegawai dalam melaksanakan tugasnya dengan tanggung jawab yang diberikan kepadanya. Kinerja yang baik akan tercapai apabila faktor-faktor yang menyebabkan terjadinya kinerja tersebut tercukupi dengan baik. Beberapa faktor yang mempengaruhi kinerja pegawai diantaranya adalah motivasi, disiplin kerja dan kompetensi. Seorang pegawai dalam mengerjakan tugasnya seringkali ditentukan 
oleh penilaian terhadap kinerjanya. Penilaian tidak hanya dilakukan untuk membantu mengawasi sumber daya organisasi, namun juga untuk mengukur tingkat efisiensi penggunaan sumber daya yang ada dan mengidentifikasi hal-hal yang perlu diperbaiki. Penilaian terhadap kinerja merupakan faktor penting untuk meningkatkan kinerja dan motivasi pegawai.

Pegawai di lingkungan Dinas Pendidikan Kota Makassar sebagai salah satu unsur utama sumber daya manusia aparatur negara mempunyai peranan yang sangat penting dalam menentukan keberhasilan penyelenggaraan pelayanan dibidang pendidikan. Oleh karena itu, pemberdayaan pegawai perlu ditingkatkan termasuk peningkatan kompetensi, motivasi, dan disiplin kerja sehingga diharapkan dapat meningkatkan kinerja pegawai. Peningkatan kinerja pegawai tersebut tidak terlepas dari upaya mengefektifkan kompetensi, motivasi, dan disiplin kerja pada Dinas Pendidikan Kota Makassar.

Kompetensi adalah kemampuan pegawai melaksanakan tugas sesuai dengan tuntutan organisasi dan persyaratan keahlian serta tuntutan profesinya. Wibowo (2010) mengemukakan bahwa pada dasarnya terdapat suatu kesepakatan mengenai elemen kompetensi, yaitu pengetahuan, keterampilan, dan perilaku. Sehubungan dengan kompetensi pegawai Dinas Pendidikan Kota Makassar yang masih memiliki pegawai dengan tingkat pendidikan SMA serta terdapat staf tenaga kontrak dengan pendidikan terakhir diploma kebidanan dan kesehatan yang tidak sesuai dengan kompetensinya, olehnya itu kompetensi pegawai perlu dikaji agar dapat diketahui pengaruhnya terhadap kinerja pegawai Dinas Pendidikan Kota Makassar.

Hasil kinerja pegawai dalam suatu organisasi tidak terlepas pula dari adanya motivasi, yaitu keadaan dalam diri pribadi seseorang yang mendorong keinginan individu untuk melakukan kegiatan-kegiatan tertentu guna mencapai suatu tujuan. Hal ini sesuai dengan pendapat yang dikemukakan oleh Ahmad Tohardi (2002) bahwa motivasi merupakan hal yang sangat penting dalam meningkatkan kegairahan atau semangat dan kepuasan kerja (work satisfaction) pegawai yang akhirnya bermuara kepada peningkatan kinerja pegawai dan tentunya juga berbias kepada peningkatan kinerja organisasi.

Seorang pegawai dikatakan disiplin jika memenuhi tiga faktor, yaitu menaati waktu kerja, melakukan pekerjaan dengan baik, dan mematuhi semua peraturan dan norma sosial. Disiplin kerja pegawai yang baik tercermin dari besarnya rasa tanggung jawab pegawai dalam menyelesaikan tugas tepat waktu. Tingkat keterlambatan pegawai yang rendah dikarenakan adanya semangat dan gairah kerja, serta meningkatnya efisiensi dan produktivitas pegawai yang ditunjukan dengan tidak adanya ketidakhadiran. Dari pengamatan penulis pada tanggal 2 maret 2016, terlihat bahwa tingkat keterlambatan pegawai masuk jam kantor masih sangat rendah. Hal ini terlihat dari daftar hadir pegawai yang masuk sesuai jadwal yaitu jam 07.30 hanya 39 orang dari total 174 pegawai di Kantor Dinas Pendidikan Kota Makassar serta beberapa pegawai yang meninggalkan kantor pada jam kerja. Hal tersebut tentu akan berpengaruh terhadap pencapaian kinerja pegawai pada Dinas Pendidikan Kota Makassar.

Salah satu faktor kurangnya motivasi dan kedisiplinan para pegawai di kantor Dinas Pendidikan Kota Makassar yaitu dipengaruhi oleh latar belakang pendidikan mereka 
yang tidak linear dengan pekerjaan yang digeluti di instansi tersebut sehingga mereka kurang mampu mencurahkan seluruh kemampuan dan keterampilan dalam mencapai prestasi kerjanya. Dalam hubungannya dengan teori Maslow, pegawai membutuhkan adanya aktualisasi diri, status, dan kekuasaan. Kebutuhan ini memerlukan dan mengharuskan seorang pekerja melakukan kegiatan belajar agar menguasai keterampilan/keahlian yang memungkinkan seorang pekerja mencapai suatu prestasi. Sehingga jika dihubungkan dengan teori dan faktor, jelas bahwa prestasi dan kemampuan akademik pegawai termasuk klasifikasi faktor sesuatu yang memotivasi dalam melaksanakan pekerjaan.

\section{Hipotesis}

1. Kompetensi, motivasi, dan disiplin kerja secara bersama-sama berpengaruh dan signifikan terhadap kinerja pegawai Dinas Pendidikan Kota Makassar.

2. Kompetensi berpengaruh positif dan signifikan terhadap kinerja pegawai Dinas Pendidikan Kota Makassar.

3. Motivasi berpengaruh positif dan signifikan terhadap kinerja pegawai dinas pendidikan Kota Makassar.

4. Disiplin kerja berpengaruh positif dan signifikan terhadap kinerja pegawai Dinas Pendidikan Kota Makassar.

\section{Kerangka Konseptual}

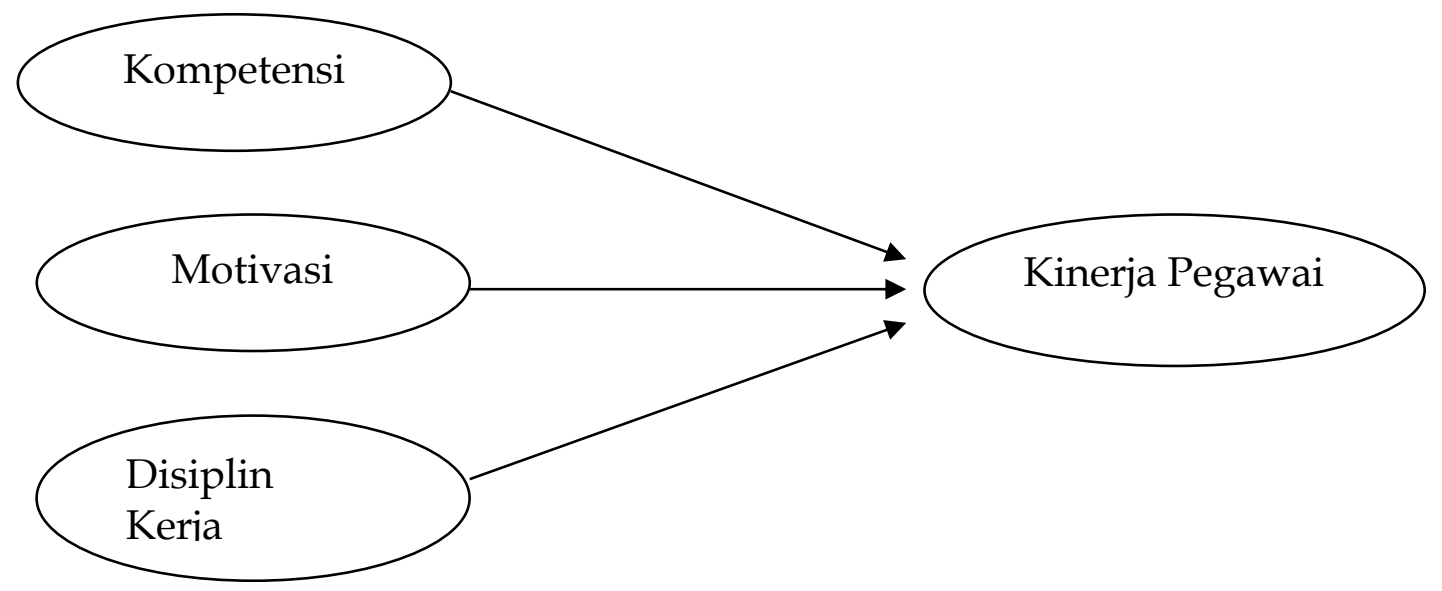

\section{METODE PENELITIAN}

Jenis penelitian ini termasuk penelitian lapangan (field research) karena data-data yang diperlukan untuk menyusun tesis diperoleh dari lapangan. Adapun penelitian ini menggunakan pendekatan kuantitatif untuk mendapatkan data yang akan diangkakan. Lokasi penelitian dilaksanakan di Dinas Pendidikan Kota Makassar yang saat itu beralamat di Jalan Letjen Hertasning, Kassi-Kassi, Kecamatan Rappocini, Kota Makassar, Sulawesi Selatan. Adapun teknik pengumpulan data dalam penelitian ini adalah observasi dan kuesioner. Populasi dalam penelitian adalah seluruh pegawai Dinas Pendidikan Kota Makassar yang berjumlah 157 orang dari lima bidang yang berbeda. Berdasarkan penelitian ini, karena jumlah 
populasinya lebih besar dari 100 orang responden, maka penulis mengambil 15\% $(23,55)$ dari jumlah populasi yang ada pada Dinas Pendidikan Kota Makassar, dibulatkan sebanyak 24 orang responden. Dengan menggunakan probability sampling, peneliti menggunakan sampel acak sederhana atau simple random sampling.

\section{HASIL PENELITIAN DAN PEMBAHASAN}

\section{Hasil}

\section{A. Hasil Uji Hipotesis}

\section{Hasil Analisis Uji R² pada Hipotesis Pertama}

\begin{tabular}{|c|c|c|c|c|c|c|c|c|c|}
\hline \multicolumn{10}{|c|}{ Model Summaryb } \\
\hline \multirow[b]{2}{*}{$\begin{array}{l}\text { Mo } \\
\text { del }\end{array}$} & \multirow[b]{2}{*}{$\mathrm{R}$} & \multirow[b]{2}{*}{$\begin{array}{c}\mathrm{R} \\
\text { Squar } \\
\mathrm{e}\end{array}$} & \multirow[b]{2}{*}{$\begin{array}{l}\text { Adjusted } \\
\text { R Square }\end{array}$} & \multirow[b]{2}{*}{$\begin{array}{l}\text { Std. Error } \\
\text { of the } \\
\text { Estimate }\end{array}$} & \multicolumn{5}{|c|}{ Change Statistics } \\
\hline & & & & & $\begin{array}{l}\text { R Square } \\
\text { Change }\end{array}$ & $\begin{array}{c}\text { F } \\
\text { Chan } \\
\text { ge }\end{array}$ & df1 & df2 & $\begin{array}{l}\text { Sig. F } \\
\text { Change }\end{array}$ \\
\hline 1 & $.698^{a}$ & .487 & .410 & 2.18191 & .487 & 6.330 & 3 & 20 & .003 \\
\hline
\end{tabular}

a. Predictors: (Constant), Disiplin Kerja, Motivasi Kerja, Kompetensi Kerja

b. Dependent Variabel: Kinerja Pegawai

Berdasarkan tabel Model Sumary di atas diperoleh nilai koefisien korelasi ganda $\left(R_{y .123}\right)=0,698$. Dengan demikian, koefisien korelasi ganda antara $X_{1}, X_{2}, X_{3}$, dengan $\mathrm{Y}$ adalah berarti atau signifikan. Sedangkan nilai $\mathrm{R}^{2}$ (koefisien determinasi) $=0,487$, yang mengandung makna bahwa 48,7\% variabel Kinerja pegawai ( $Y$ ) dipengaruhi oleh Kompetensi kerja $\left(X_{1}\right)$, motivasi kerja $\left(X_{2}\right)$, dan disiplin kerja $\left(X_{3}\right)$.

\section{Hasil Uji F}

\begin{tabular}{|c|c|c|c|c|c|c|}
\hline \multicolumn{7}{|c|}{ ANOVAa $^{a}$} \\
\hline & Model & $\begin{array}{l}\text { Sum of } \\
\text { Squares }\end{array}$ & df & Mean Square & $\mathrm{F}$ & Sig. \\
\hline \multirow[t]{3}{*}{1} & Regression & 90.410 & 3 & 30.137 & 6.330 & $.003^{b}$ \\
\hline & Residual & 95.215 & 20 & 4.761 & & \\
\hline & Total & 185.625 & 23 & & & \\
\hline
\end{tabular}

a. Dependent Variabel: Kinerja Pegawai

b. Predictors: (Constant), Disiplin Kerja, Motivasi Kerja, Kompetensi Kerja

Sedangkan nilai $F_{\text {hitung }}=6,330$. Nilai $F_{\text {tabel }}$ diperoleh dengan menggunakan tabel $F$ dengan cara:

$F_{\text {tabel }}=F_{((1-\alpha)(d f \text { pembilang }=m),(d f \text { penyebut }=n-m-1))}$

Keterangan:

$\alpha=0,05$ (taraf signifikansi)

$\mathrm{m}=$ banyak variabel bebas

$\mathrm{n}=$ banyak sampel

sehingga

df pembilang $=m=3$

$\mathrm{df}$ penyebut $=\mathrm{n}-\mathrm{m}-1=24-3-1=20$

$F_{\text {tabel }}=F_{(1-0,05)(3,20)}=3,10$ 
Ternyata $F_{\text {hitung }}=6,330>F_{\text {tabel }}=3,10$ sehingga $\mathrm{H}_{0}$ ditolak.

Dengan demikian, kompetensi, motivasi, dan disiplin kerja secara bersama-sama berpengaruh dan signifikan terhadap kinerja pegawai Dinas Pendidikan Kota Makassar.

\section{Hasil Analisis Uji R² pada Hipotesis Kedua}

\begin{tabular}{|c|c|c|c|c|c|c|c|c|c|}
\hline \multicolumn{10}{|c|}{ Model Summaryb } \\
\hline \multirow[b]{2}{*}{$\begin{array}{l}\mathrm{M} \\
\mathrm{od} \\
\mathrm{el}\end{array}$} & \multirow[b]{2}{*}{$\mathrm{R}$} & \multirow[b]{2}{*}{$\begin{array}{l}\mathrm{R} \\
\text { Squa } \\
\text { re }\end{array}$} & \multirow[b]{2}{*}{$\begin{array}{l}\text { Adjusted } \\
\text { R Square }\end{array}$} & \multirow{2}{*}{$\begin{array}{l}\text { Std. } \\
\text { Error of } \\
\text { the } \\
\text { Estimate }\end{array}$} & \multicolumn{5}{|c|}{ Change Statistics } \\
\hline & & & & & $\begin{array}{l}\text { R Square } \\
\text { Change }\end{array}$ & $\begin{array}{c}\text { F } \\
\text { Chan } \\
\text { ge }\end{array}$ & df1 & df2 & $\begin{array}{l}\text { Sig. F } \\
\text { Change }\end{array}$ \\
\hline 1 & $.467 a$ & .218 & .182 & 2.56897 & .218 & 6.127 & 1 & 22 & .021 \\
\hline
\end{tabular}

Berdasarkan tabel Model Sumary di atas, diperoleh nilai koefisien korelasi $\left(\mathrm{R}_{\mathrm{y} . \times 1}\right)=$ 0,467 . Dengan demikian, koefisien korelasi antara $\mathrm{X}_{1}$ dengan $\mathrm{Y}$ adalah berarti atau signifikan. Sedangkan nilai $\mathrm{R}^{2}$ (koefisien determinasi) $=0,218$, yang mengandung makna bahwa 21,8\% variabel kinerja pegawai $(Y)$ dipengaruhi oleh kompetensi kerja $\left(\mathrm{X}_{1}\right)$.

\section{Hasil Analisis Uji t (Uji Parsial) pada Hipotesis Kedua}

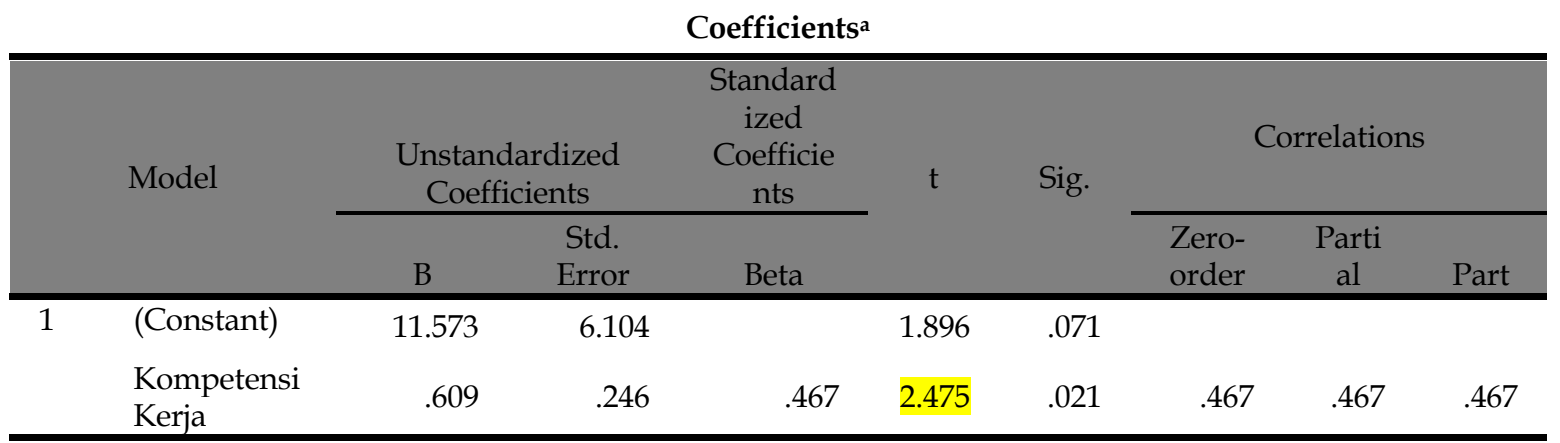

a. Dependent Variabel: Kinerja Pegawai

Berdasarkan tabe Coefficients di atas, diperoleh nilai $t_{\text {hitung }}=2,475$. Nilai $t_{\text {tabel }}$ dapat dicari dengan menggunakan tabel $t$-student. Nilai $\alpha$ yang digunakan adalah 0,05 dengan uji pihak kanan. Dilakukan uji pihak kanan karena hipotesis mengandung kata "positif:

$t_{\text {tabel }}=t_{(0,05 ;(n-2)}=t_{(0,05,3(24-2)}=t_{(0,05 ; 22)}=1,717$

Ternyata $t_{\text {hitung }}=2,475>t_{\text {tabel }}=1,717$, maka $\mathrm{H}_{0}$ ditolak. Dengan demikian, kompetensi berpengaruh positif dan signifikan terhadap kinerja pegawai Dinas Pendidikan Kota Makassar. 


\section{Hasil Analisis Uji R² pada Hipotesis Ketiga}

\begin{tabular}{|c|c|c|c|c|c|c|c|c|c|}
\hline \multicolumn{10}{|c|}{ Model Summary ${ }^{b}$} \\
\hline \multirow[b]{2}{*}{$\begin{array}{l}\mathrm{M} \\
\mathrm{od} \\
\mathrm{el}\end{array}$} & \multirow[b]{2}{*}{$\mathrm{R}$} & \multirow[b]{2}{*}{$\begin{array}{c}\mathrm{R} \\
\text { Squar } \\
\mathrm{e}\end{array}$} & \multirow[b]{2}{*}{$\begin{array}{l}\text { Adjusted } \\
\text { R Square }\end{array}$} & \multirow{2}{*}{$\begin{array}{l}\text { Std. } \\
\text { Error of } \\
\text { the } \\
\text { Estimate }\end{array}$} & \multicolumn{5}{|c|}{ Change Statistics } \\
\hline & & & & & $\begin{array}{l}\text { R Square } \\
\text { Change }\end{array}$ & $\begin{array}{c}\text { F } \\
\text { Chan } \\
\text { ge }\end{array}$ & df1 & df2 & $\begin{array}{l}\text { Sig. F } \\
\text { Change }\end{array}$ \\
\hline 1 & $.503^{a}$ & .253 & .219 & 2.51030 & .253 & 7.457 & 1 & 22 & .012 \\
\hline
\end{tabular}

a. Predictors: (Constant), Motivasi Kerja

b. Dependent Variabel: Kinerja Pegawai

Berdasarkan tabel Model Summary di atas, diperoleh nilai koefisien korelasi $\left(\mathrm{R}_{\mathrm{y} . \mathrm{x} 2}\right)$ sebesar 0,503. Dengan demikian, koefisien korelasi antara $\mathrm{X}_{2}$ dengan $\mathrm{Y}$ adalah berarti atau signifikan. Sedangkan nilai $R^{2}$ (koefisien determinasi) $=0,253$, yang mengandung makna bahwa 25,3\% variabel kinerja pegawai (Y) dipengaruhi oleh motivasi kerja $\left(\mathrm{X}_{2}\right)$.

\section{Hasil Analisis Uji t (Uji Parsial) pada Hipotesis Ketiga}

\begin{tabular}{|c|c|c|c|c|c|c|c|c|c|}
\hline \multicolumn{10}{|c|}{ Coefficients ${ }^{a}$} \\
\hline & \multirow[t]{2}{*}{ Model } & \multicolumn{2}{|c|}{$\begin{array}{c}\text { Unstandardized } \\
\text { Coefficients }\end{array}$} & $\begin{array}{l}\text { Standardi } \\
\text { zed } \\
\text { Coefficien } \\
\text { ts }\end{array}$ & \multirow[t]{2}{*}{$\mathrm{T}$} & \multirow[t]{2}{*}{ Sig. } & \multicolumn{3}{|c|}{ Correlations } \\
\hline & & B & $\begin{array}{l}\text { Std. } \\
\text { Error }\end{array}$ & Beta & & & $\begin{array}{l}\text { Zero- } \\
\text { order }\end{array}$ & $\begin{array}{l}\text { Parti } \\
\text { al }\end{array}$ & Part \\
\hline \multirow[t]{2}{*}{1} & (Constant & 11.890 & 5.420 & & 2.194 & .039 & & & \\
\hline & $\begin{array}{l}\text { Motivasi } \\
\text { Kerja }\end{array}$ & .586 & .215 & .503 & 2.731 & .012 & .503 & .503 & .503 \\
\hline
\end{tabular}

a. Dependent Variabel: Kinerja Pegawai

Berdasarkan tabe Coefficients di atas, diperoleh nilai $t_{\text {hitung }}=2,731$. Nilai $t_{t a b a l}$ dapat dicari dengan menggunakan tabel $t$-student. Nilai $\alpha$ yang digunakan adalah 0,05 dengan uji pihak kanan. Dilakukan uji pihak kanan karena hipotesis mengandung kata "positif:

$t_{\text {tabel }}=t_{(0,05 ;(n-2)}=t_{(0,05,(24-2)}=t_{(0,05 ; 22)}=1,717$

Ternyata $t_{\text {hitung }}=2,731>t_{\text {tabel }}=1,717$,maka $H_{0}$ ditolak. Dengan demikian, motivasi berpengaruh positif dan signifikan terhadap kinerja pegawai Dinas Pendidikan Kota Makassar.

\section{Hasil Analisis Uji R² pada Hipotesis Keempat}

\begin{tabular}{|c|c|c|c|c|c|c|c|c|c|}
\hline \multicolumn{10}{|c|}{ Model Summaryb } \\
\hline \multirow[b]{2}{*}{$\begin{array}{l}\text { M } \\
\text { od } \\
\text { el }\end{array}$} & \multirow[b]{2}{*}{$\mathrm{R}$} & \multirow[b]{2}{*}{$\begin{array}{c}\mathrm{R} \\
\text { Squa } \\
\text { re }\end{array}$} & \multirow[b]{2}{*}{$\begin{array}{c}\text { Adjuste } \\
\text { d R } \\
\text { Square }\end{array}$} & \multirow{2}{*}{$\begin{array}{l}\text { Std. } \\
\text { Error of } \\
\text { the } \\
\text { Estimate }\end{array}$} & \multicolumn{5}{|c|}{ Change Statistics } \\
\hline & & & & & $\begin{array}{c}\text { R } \\
\text { Square } \\
\text { Change }\end{array}$ & $\begin{array}{c}\text { F } \\
\text { Chan } \\
\text { ge }\end{array}$ & df1 & df2 & $\begin{array}{l}\text { Sig. F } \\
\text { Change }\end{array}$ \\
\hline 1 & $.653^{\mathrm{a}}$ & .426 & .400 & 2.19979 & .426 & $\begin{array}{r}16.36 \\
0\end{array}$ & 1 & 22 & .001 \\
\hline
\end{tabular}

a. Predictors: (Constant), Disiplin Kerja 
b. Dependent Variabel: Kinerja Pegawai

Berdasarkan tabel Model Sumary di atas, diperoleh nilai koefisien korelasi $\left(\mathrm{R}_{\mathrm{y} . \times 3}\right)=$ 0,653 . Dengan demikian, koefisien korelasi antara $X_{3}$ dengan $Y$ adalah berarti atau signifikan. Sedangkan nilai $\mathrm{R}^{2}$ (koefisien determinasi) $=0,426$, yang mengandung makna bahwa 42,6\% variabel kinerja pegawai $(\mathrm{Y})$ dipengaruhi oleh disiplin kerja $\left(\mathrm{X}_{3}\right)$.

\section{Hasil Analisis Uji t (Uji Parsial) pada Hipotesis Keempat}

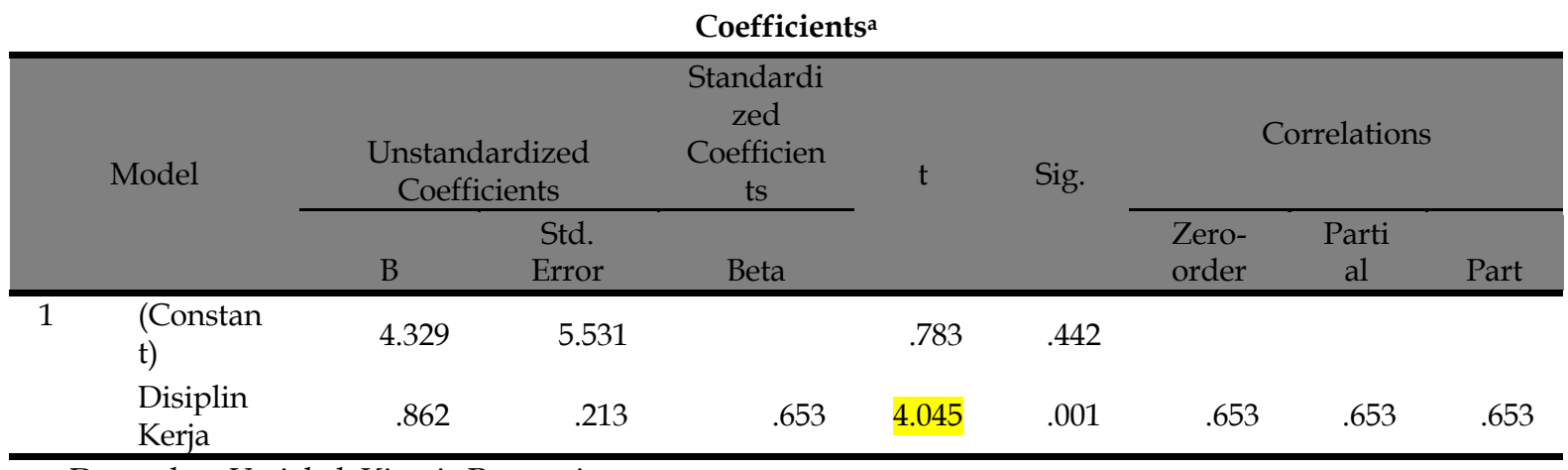

a. Dependent Variabel: Kinerja Pegawai

Berdas

arkan tabel Coefficients di atas, diperoleh nilai $t_{\text {hitung }}=4,045$. Nilai $t_{\text {tabel }}$ dapat dicari dengan menggunakan tabel $t$-student. Nilai $\alpha$ yang digunakan adalah 0,05 dengan uji pihak kanan. Dilakukan uji pihak kanan karena hipotesis mengandung kata "positif:

$t_{\text {tabel }}=t_{(0,05 ;(n-2)}=t_{(0,05,3(24-2)}=t_{(0,05 ; 22)}=1,717$

Ternyata $t_{\text {hitung }}=4,045>t_{\text {tabel }}=1,717$, maka $H_{0}$ ditolak. Dengan demikian, disiplin kerja berpengaruh positif dan signifikan terhadap kinerja pegawai Dinas Pendidikan Kota Makassar.

\section{Hasil Analisis Uji Korelasi yang Paling Dominan}

\begin{tabular}{|c|c|c|c|c|c|}
\hline \multicolumn{6}{|c|}{ Correlations } \\
\hline & & $\begin{array}{c}\text { Kinerja } \\
\text { Pegawai }\end{array}$ & $\begin{array}{l}\text { Kompetensi } \\
\text { Kerja }\end{array}$ & $\begin{array}{l}\text { Motivasi } \\
\text { Kerja }\end{array}$ & $\begin{array}{l}\text { Disiplin } \\
\text { Kerja }\end{array}$ \\
\hline \multirow[t]{4}{*}{ Pearson Correlation } & Kinerja Pegawai & 1.000 & .467 & .503 & .653 \\
\hline & Kompetensi Kerja & .467 & 1.000 & .614 & .484 \\
\hline & Motivasi Kerja & .503 & .614 & 1.000 & .442 \\
\hline & Disiplin Kerja & .653 & .484 & .442 & 1.000 \\
\hline \multirow[t]{4}{*}{ Sig. (1-tailed) } & Kinerja Pegawai & & .011 & .006 & .000 \\
\hline & Kompetensi Kerja & .011 & & .001 & .008 \\
\hline & Motivasi Kerja & .006 & .001 & & .015 \\
\hline & Disiplin Kerja & .000 & .008 & .015 & . \\
\hline \multirow[t]{4}{*}{$\mathrm{N}$} & Kinerja Pegawai & 24 & 24 & 24 & 24 \\
\hline & Kompetensi Kerja & 24 & 24 & 24 & 24 \\
\hline & Motivasi Kerja & 24 & 24 & 24 & 24 \\
\hline & Disiplin Kerja & 24 & 24 & 24 & 24 \\
\hline
\end{tabular}




\section{Hasil Analisis Uji R ${ }^{2}$ Koefisien Korelasi yang Paling Tinggi}

\begin{tabular}{|c|c|c|c|c|c|c|c|c|c|}
\hline \multirow[b]{3}{*}{$\begin{array}{l}\text { Mo } \\
\text { del }\end{array}$} & \multicolumn{8}{|c|}{ Model Summaryb } & \\
\hline & \multirow[b]{2}{*}{$\mathrm{R}$} & \multirow{2}{*}{$\begin{array}{l}\mathrm{R} \\
\text { Squar } \\
\mathrm{e}\end{array}$} & \multirow[b]{2}{*}{$\begin{array}{l}\text { Adjusted } \\
\text { R Square }\end{array}$} & \multirow[b]{2}{*}{$\begin{array}{l}\text { Std. Error } \\
\text { of the } \\
\text { Estimate }\end{array}$} & \multicolumn{5}{|c|}{ Change Statistics } \\
\hline & & & & & $\begin{array}{l}\text { R Square } \\
\text { Change }\end{array}$ & $\begin{array}{c}\mathrm{F} \\
\text { Chang } \\
\mathrm{e}\end{array}$ & df1 & $\mathrm{df} 2$ & $\begin{array}{l}\text { Sig. F } \\
\text { Change }\end{array}$ \\
\hline 1 & $.653^{a}$ & .426 & .400 & 2.19979 & .426 & 16.360 & 1 & 22 & .001 \\
\hline
\end{tabular}

Berdasarkan output di atas, diperoleh informasi bahwa koefisien korelasi yang paling tinggi adalah koefisien korelasi antara variabel disiplin kerja $\left(X_{3}\right)$ dengan kinerja pegawai $(Y)$ sebesar 0,653 . Sedangkan koefisien determinasi $\left(R^{2}\right)$ antara variabel disiplin kerja $\left(\mathrm{X}_{3}\right)$ dengan kinerja pegawai $(\mathrm{Y})$ adalah 0,426 , yang mengandung makna bahwa $42,6 \%$ variabel kinerja pegawai (Y) dipengaruhi oleh disiplin kerja $\left(X_{3}\right)$. Dengan demikian, terbukti bahwa variabel disiplin kerja merupakan variabel yang paling dominan berpengaruh terhadap kinerja pegawai Dinas Pendidikan Kota Makassar.

\section{Pembahasan}

\section{Pengaruh Kompetensi, Motivasi, dan Disiplin Kerja terhadap Kinerja Pegawai}

Kompetensi motivasi dan disiplin kerja dipercaya memiliki pengaruh terhadap kinerja pegawai. Berdasarkan hasil analisis uji $\mathrm{R}^{2}$ dalam mencari pengaruh kompetensi, motivasi, dan disiplin kerja terhadap kinerja pegawai, didapatkan angka 0,487 pada koefisien determinasi yang berarti bahwa 48,7\% variable kinerja pegawai dipengaruhi oleh kompetensi kerja motivasi kerja dan disiplin kerja. Sedangkan hasil analisis dengan menggunakan Anova menghasilkan nilai Ftable adalah 3,10 dan nilai Fhitung adalah 6,330 dengan taraf signifikansi 0,05. Dikarenakan Fhitung lebih besar dari Ftable, maka Ho ditolak. Dengan demikian, kompetensi, motivasi, dan disiplin kerja secara bersama-sama berpengaruh dan signifikan terhadap kinerja pegawai kantor Dinas Pendidikan Kota Makassar.

Penelitian serupa telah dilakukan oleh Suparno dalam mencari pengaruh motivasi, disiplin kerja, dan kompetensi terhadap kinerja pegawai Dinas Pendidikan Kabupaten Sragen pada tahun 2014. Hasil penelitian dari Suparno juga menunjukkan bahwa ketiga variable tersebut berpengaruh positif dan signifikan terhadap kinerja pegawai. Adanya pengaruh positif dan signifikan dari ketiga variable juga sangat ditentukan oleh besarnya peran indikator kinerja pegawai yang membentuknya, diantaranya: ketepatan penyelesaian tugas dengan pertanyaan pegawai menyelesaikan tugas yang diberikan dengan tepat waktu dan mereka menyelesaikan tugas sesuai dengan standar kerja, kesesuaian jam kerja dengan pertanyaan pegawai bekerja sesuai dengan jam kerja yang ditetapkan dan menyelesaikan pekerjaan sesuai dengan target yang ditetapkan, tingkat kehadiran dengan pertanyaan pegawai jarang absen jika tidak benar-benar dalam keadaan mendesak dan mereka selalu hadir tepat waktu pada jam kerja, dan kerjasama antar pegawai dengan pertanyaan pegawai bisa bekerja sama dengan rekan kerja lainnya dan mereka senang membantu rekan kerja yang kesulitan dalam bekerja. Adapun 
bagaimana masing-masing variable berpengaruh terhadap kinerja pegawai akan dijelaskan lebih lanjut pada bagian selanjutnya.

\section{Pengaruh Kompetensi terhadap Kinerja Pegawai}

Kompetensi adalah kemampuan pegawai melaksanakan tugas sesuai dengan tuntutan organisasi dan persyaratan keahlian serta tuntutan profesinya. Hasil pengujian hipotesis pada penelitian ini secara statistik menunjukkan variabel kompetensi mempunyai t-hitung lebih besar dari t-tabel $(2,475>1,717)$ dan nilai signifikansi 0,05 yang berarti bahwa hipotesis kedua dalam penelitian ini diterima, yaitu kompetensi berpengaruh positif dan signifikan terhadap kinerja pegawai Dinas Pendidikan Kota Makassar. Pengaruh kompetensi yang positif dan signifikan mengindikasikan bahwa kompetensi menjadi sangat berguna untuk membantu meningkatkan kinerja pegawai.

Adanya pengaruh positif dan signifikan dari variabel kompetensi juga sangat ditentukan oleh besarnya peran indikator penelitian yang membentuknya, diantaranya: pengalaman kerja dengan pertanyaan lama kerja atau masa kerja pegawai memudahkan mereka dalam mengerjakan tugas dan pengalaman kerja pegawai membantu mengurangi kesalahan yang mereka lakukan pada saat bekerja, latar belakang pendidikan dengan pertanyaan pegawai paham dengan pekerjaan yang mereka jalani karena telah mempelajari sebelumnya dan latar belakang pendidikan mereka sesuai dengan pekerjaan mereka sekarang, memiliki keahlian atau pengetahuan dengan pertanyaan mereka selalu berusaha untuk berpikir strategis demi kemajuan diri dan berusaha memunculkan ide baru untuk kemajuan organisasi, dan keterampilan dengan pertanyaan pegawai memiliki keterampilan yang baik untuk melakukan pekerjaan dan mendapatkan pelatihan dan pengembangan keterampilan untuk mendukung pekerjaan mereka. Dengan memperdayakan indikator-indokator tersebut diharapkan dapat meningkatkan kinerja pegawai di Dinas Pendidikan Kota Makassar.

Hasil penelitian ini sesuai dengan konsep dan teori kompetensi yang dikemukakan oleh (Prihadi, 2004) bahwa kompetensi menghasilkan kinerja yang efektif. Ini berarti kompetensi mempunyai hubungan yang erat dengan kinerja. Bisa dikatakan bila pegawai memiliki kompetensi di bidangnya, maka pegawai tersebut akan meningkatkan kinerja yang efektif.

Menurut Lyle Spencer dan Signe Spencer dalam (Moeheriono, 2012), kompetensi adalah karakteristik yang mendasari seseorang berkaitan dengan efektivitas kinerja individu dalam pekerjaannya atau karakteristik individu yang memiliki hubungan kausal atau sebagai sebab akibat dengan kriteria yang dijadikan acuan, efektif atau berkinerja prima superior ditempat kerja pada situasi tertentu. Hal ini sejalan dengan jawaban sangat setuju dari staf bahwa mereka paham dengan pekerjaan yang mereka jalani karena telah mempelajari sebelumnya. Hal ini juga diperkuat oleh (Wibowo, 2010) yang mengatakan bahwa kompetensi adalah suatu kemampuan untuk melaksanakan atau melakukan suatu pekerjaan atau tugas yang dilandasi atas keterampilan dan pengetahuan serta didukung oleh sikap kerja yang dituntut oleh pekerjaan tersebut.

Pada indikator pegawai memiliki keahlian atau pengetahuan dengan pertanyaan mereka selalu berusaha untuk berpikir strategis demi kemajuan diri dan berusaha 
memunculkan ide baru untuk kemajuan organisasi, (Wirawan, 2009) berpendapat bahwa kompetensi adalah karakteristik pengetahuan, keterampilan, perilaku, dan pengalaman untuk melakukan suatu pekerjaan atau peran tertentu secara efektif.

Menurut Siagian (2002), pendidikan dapat mempengaruhi kompetensi seseorang. Semakin tinggi pendidikan seseorang, makin semakin besar keinginannya untuk memanfaatkan pengetahuan dan keterampilannya dalam pelaksanaan tugasnya. Disamping itu, pegawai yang memiliki pendidikan yang lebih tinggi diharapkan mampu memberikan masukan-masukan yang bermanfaat kepada atasan dalam upaya peningkatan pelaksanaan tugas dikarenakan tidak semua pegawai memiliki latar belakang pendidikan yang sama dengan pekerjaan yang mereka tekuni sekarang.

Hal ini didukung dengan adanya responden $(37,5 \%)$ yang menyatakan tidak setuju dengan indikator latar belakang pendidikan sesuai dengan pekerjaan saya sekarang. Hal ini diperkuat dengan adanya pegawai Dinas Pendidikan Kota Makassar yang masih memiliki tenaga kontrak dengan pendidikan terakhir diploma kebidanan dan kesehatan yang tidak sesuai dengan kompetensinya. Akan tetapi pada indikator lain, mereka mendapatkan pelatihan dan pengembangan keterampilan untuk mendukung pekerjaan mereka sekarang dan terdapat $62,5 \%$ responden yang setuju dengan indikator tersebut. Jadi meskipun beberapa pegawai memiliki latar belakang pendidikan yang kurang linear dengan kompetensi mereka sekarang, mereka tetap dapat bekerja maksimal dengan diberikannya pembekalan berupa pelatihan dan pengembangan keterampilan.

\section{Pengaruh Motivasi terhadap Kinerja Pegawai}

Motivasi adalah dorongan dalam diri seseorang dalam menangani pekerjaan dan berkaitan dengan kebutuhan dirinya maupun pekerjaannya. Hasil pengujian hipotesis pada penelitian ini secara statistik menunjukkan variabel motivasi mempunyai t-hitung lebih besar dari t-tabel $(2,731>1,717)$. Hal ini menunjukkan bahwa motivasi berpengaruh positif dan signifikan terhadap kinerja pegawai Dinas Pendidikan Kota Makassar. Ini artinya motivasi yang diukur melalui delapan indikator yaitu: motivasi internal (selalu berupaya mencurahkan kemampuan, keterampilan, dan kecakapan untuk mencapai prestasi diri, mampu menciptakan sosialisasi bergaul dengan teman sekantor, membutuhkan pengakuan dan penghargaan diri dalam lingkungan kerja, dan membutuhkan kenaikan jabatan dan gaji) dan motivasi eksternal (instansi telah memberikan peluang dan kesempatan untuk mengembangkan keterampilan dan kemampuan pegawai, atasan memberikan reward bagi pegawai yang berprestasi, instansi telah memberikan istirahat dan cuti khusus yang sesuai dengan hak pegawai, serta atasan melakukan pengontrolan terhadap pegawai dan memberikan teguran bagi pegawai yang melanggar peraturan kerja) berpengaruh positif dan signifikan terhadap kinerja pegawai Dinas Pendidikan Kota Makassar.

Motivasi harus dipahami dari segi kebutuhan manusia karena pada hakekatnya setiap pegawai memiliki motivasi yang berbeda-beda dalam bekerja. Pimpinan memiliki kewajiban untuk selalu memotivasi pegawai agar meningkatkan kinerjanya. Semakin baik motivasi yang diberikan oleh atasan terhadap pegawai, maka semakin baik pula kinerja yang dihasilkan pegawai. 
Akan tetapi terdapat satu temuan yang cukup unik bagi peneliti bahwa terdapat $33,3 \%$ responden yang menjawab tidak setuju dengan indikator mereka membutuhkan pengakuan dan penghargaan diri dalam lingkungan kerja. Di satu sisi, penulis beranggapan bahwa sebagai pegawai kita membutuhkan pengakuan dan penghargaan diri dari sekitar. Akan tetapi di sisi lain, sebagaimana responden berpendapat, mereka hanya ingin berupaya mencurahkan kemampuan keterampilan dan kecakapan mereka untuk mencapai tujuan instansi tanpa harus membutuhkan penghargaan diri dan pengakuan dari lingkungan kerja.

Sebagai pendukung temuan di atas, terdapat 54\% responden yang setuju bahwa instansi telah memberikan peluang dan kesempatan untuk mengembangkan keterampilan dan kemampuan mereka. Hal ini memperkuat adanya kemauan para pegawai dalam mengaktualisasikan diri dan adanya kesempatan yang telah diberikan oleh instansi dalam mengembangkan keterampilan mereka meski pada akhirnya mereka kurang mendapatkan pengakuan dan penghargaan diri.

Pemahaman terhadap peran motivasi kerja dalam meningkatkan kinerja pegawai mengarahkan pada pengertian betapa pentingnya motivasi kerja sebagai bagian dari upaya perusahaan untuk meningkatkan kesejahteraan pegawai yang berakhir pada peningkatan kinerja. Dengan kinerja yang tinggi di masing-masing aspek sesuai bidang tugas dan tanggung jawab pegawai, hal ini akan menciptakan suatu sinergi yang baik dalam instansi sehingga dapat berkembang dengan baik.

\section{Pengaruh Disiplin Kerja terhadap Kinerja Pegawai}

Disiplin kerja adalah sikap pegawai untuk menaati, mematuhi, serta sanggup menjalankan dan melaksanakan seluruh aturan dan kebijakan organisasi untuk menjaga ketertiban kerja. Hasil pengujian hipotesis pada penelitian ini secara statistik menunjukkan variabel disiplin kerja mempunyai t-hitung > t-tabel $(2,920>$ 1,717 ) dan nilai signifikansi 0,004 yang berarti bahwa hipotesis keempat diterima yaitu disiplin kerja berpengaruh positif dan signifikan terhadap kinerja pegawai Dinas Pendidikan Kota Makassar. Hal ini mengindikasikan bahwa peningkatan kinerja pegawai di Dinas Pendidikan Kota Makassar dipengaruhi oleh disiplin kerja. Pengaruh yang positif terhadap kinerja mengindikasikan bahwa pegawai yang memiliki tingkat kedisiplinan yang baik cenderung memiliki kinerja yang baik pula.

Adanya pengaruh positif dan signifikan dari variabel disiplin kerja juga sangat ditentukan oleh besarnya peran indikator penelitian yang membentuknya diantaranya: ketepatan waktu dengan pertanyaan pegawai selalu datang dan masuk kerja tepat waktu dan mereka selalu mengerjakan tugas sesuai waktu yang ditetapkan dan tidak suka menunda pekerjaan yang harus diselesaikan, menggunakan peralatan kantor dengan baik dengan pertanyaan pegawai menggunakan peralatan kantor atau barang milik negara dengan baik dan ikut menjaga dan merawatnya dan mereka menggunakan barang milik negara seperlunya dan langsung mengembalikannya jika telah digunakan, tanggungjawab tinggi dengan pertanyaan pegawai selalu menjalankan tugas dengan baik dan berusaha menyelesaikannya secara maksimal dan pegawai berusaha dengan lebih keras daripada yang seharusnya, dan ketaatan terhadap aturan kantor dengan pertanyaan pegawai memahami tata tertib dan menjalankan perintah dengan benar dan pegawai selalu memakai pakaian dinas secara lengkap dan rapi. Dengan 
memperdayakan kedelapan indikator tersebut diharapkan dapat meningkatkan kinerja pegawai di Dinas Pendidikan Kota Makassar.

Hasil penelitian ini sesuai dengan konsep disiplin oleh Hasibuan (2005: 140) yang mengatakan bahwa disiplin merupakan kesadaran dan kesediaan seseorang mentaati semua peraturan organisasi dan norma-norma sosial yang berlaku. Menurut Budi Setiyawan dan Waridin (2006), disiplin kerja merupakan bagian dari faktor kinerja. Disiplin kerja harus dimiliki setiap pegawai dan harus dibudayakan di kalangan pegawai agar bisa mendukung tercapainya tujuan organisasi karena merupakan wujud dari kepatuhan terhadap aturan kerja.

\section{Variabel yang Paling Dominan Berpengaruh terhadap Kinerja Pegawai}

Hasil pengujian hipotesis pada penelitian ini secara statistik menunjukkan bahwa dari ketiga variabel bebas yang diteliti, variabel disiplin kerja mempunyai pengaruh yang paling dominan jika dibandingkan dengan variabel kompetensi dan motivasi karena memiliki nilai beta atau standardized coefficient yang lebih besar dari variabel lainnya, yakni sebesar 0,653. Hasil ini menunjukkan bahwa hipotesis kelima juga diterima yang berarti variabel disiplin kerja merupakan variabel yang paling dominan berpengaruh terhadap kinerja pegawai Dinas Pendidikan Kota Makassar. Hal ini mengindikasikan bahwa variabel disiplin kerja berperan dalam menentukan peningkatan kinerja pegawai di Dinas Pendidikan Kota Makassar dibandingkan dengan variabel motivasi dan kompetensi.

Dalam variable disiplin kerja, terdapat $79,2 \%$ responden setuju bahwa mereka harus berusaha dengan lebih keras daripada yang seharusnya. Hal ini tentunya menjadi poin tambahan bagi pegawai Dinas Pendidikan Kota Makassar bahwa mereka akan selalu bekerja lebih giat dari standar yang telah ditetapkan. Olehnya itu, sudah sepantasnya variable disiplin kerja memiliki pengaruh yang paling besar terhadap kinerja pegawai. Menurut hemat peneliti, selama seorang pegawai disiplin dalam bekerja, maka kompetensi juga ikut meningkat. Ditambah lagi selama seseorang pegawai selalu bersikap disiplin, maka sudah pasti mereka memiliki motivasi yang tinggi dalam bekerja.

Keteraturan adalah ciri utama organisasi dan disiplin adalah salah satu metode untuk memelihara keteraturan tersebut. Tujuan utama disiplin adalah untuk meningkatkan efisiensi semaksimal mungkin dengan cara mencegah pemborosan waktu dan energi. Selain itu, disiplin mencoba untuk mencegah kerusakan atau kehilangan harta benda, mesin, peralatan dan perlengkapan kerja disebabkan oleh ketidak hati-hatian, senda gurau, atau pencurian. Disiplin mencoba mengatasi kesalahan dan keteledoran yang disebabkan karena kurang perhatian, ketidakmampuan, keterlambatan atau kemalasan. Disiplin juga berusaha untuk mengatasi perbedaan pendapat antar karyawan dan mencegah ketidaktaatan yang disebabkan oleh salah pengertian dan salah penafsiran. Perusahaan mempunyai peraturanperaturan yang menuntut karyawan untuk patuh terhadapnya sehingga karyawan mempunyai disiplin kerja yang tinggi agar tujuan organisasi dapat dicapai. Hasibuan (2013:193) menyatakan "Kedisiplinan merupakan fungsi operatif manajemen sumber daya manusia yang terpenting karena semakin baik disiplin karyawan, semakin tinggi prestasi yang dicapainya. Tanpa disiplin karyawan yang baik, sulit bagi organisasi perusahaan mencapai hasil yang optimal". Hariandja 
(2000) menyatakan "Peningkatan disiplin menjadi bagian yang penting dalam manajemen sumber daya manusia sebagai faktor penting dalam meningkatkan kinerja".

\section{KESIMPULAN}

Berdasarkan pembahasan bab sebelumnya dan setelah melakukan uji empirik mengenai hubungan antara variabel kompetensi, motivasi, dan disiplin kerja terhadap kinerja pegawai pada Dinas Pendidikan Kota Makassar, maka penulis dapat mengambil kesimpulan dari hasil penelitian sebagai berikut:

1. Kompetensi, motivasi dan disiplin kerja bersama-sama mempunyai pengaruh terhadap kinerja pegawai Dinas Pendidikan Kota Makassar.

2. Kompetensi berpengaruh positif dan signifikan terhadap kinerja pegawai Dinas Pendidikan Kota Makassar. Hal ini mengindikasikan bahwa kompetensi menjadi sangat berguna untuk membantu peningkatan kinerja pegawai di Dinas Pendidikan Kota Makassar.

3. Motivasi berpengaruh positif dan signifikan terhadap kinerja pegawai Dinas Pendidikan Kota Makassar. Hal ini mengindikasikan bahwa peningkatan kinerja pegawai di Dinas Pendidikan Kota Makassar dipengaruhi oleh motivasi baik intrinsik maupun ekstrinsik.

4. Disiplin kerja berpengaruh positif dan signifikan terhadap kinerja pegawai Dinas Pendidikan Kota Makassar. Hal ini mengindikasikan bahwa peningkatan kinerja pegawai di Dinas Pendidikan Kota Makassar dipengaruhi oleh disiplin kerja.

5. Variabel disiplin kerja lebih dominan mempengaruhi kinerja pegawai jika dibandingkan dengan variabel motivasi dan kompetensi pada Dinas Pendidikan Kota Makassar. Hal ini tentunya menjadi poin tambahan bagi pegawai Dinas Pendidikan Kota Makassar bahwa mereka akan selalu bekerja lebih giat dari standar yang telah ditetapkan. Menurut hemat peneliti, selama seorang pegawai disiplin dalam bekerja, maka kompetensi juga ikut meningkat. Ditambah lagi selama seseorang pegawai selalu bersikap disiplin, maka sudah pasti mereka memiliki motivasi yang tinggi dalam bekerja

\section{DAFTAR PUSTAKA}

Ahmad, T. (2002). Manajemen Sumber Daya Manusia. Bandung: Mandar Maju.

Setiyawan B. dan Waridin. (2006). Pengaruh Disiplin Kerja Karyawan dan Budaya Organisasi Terhadap Kinerja di Divisi Radiologi RSUP Dokter Kariadi Semarang. JRBI. Vol 2. No.2: 190-210.

Hariandja, M.T.E. (2000). Manajemen Sumber Daya Manusia. Penerbit Grasindo. Jakarta.

Moeheriono. (2012). Pengukuran Kinerja Berbasis Kompetensi. Jakarta: PT Raja Grafindo Persada.

Prihadi, S. (2004). Kinerja, Aspek Pengukuran. Jakarta: PT. Gramedia Pustaka.

Ruky, A. (2006). Sistim Manajemen Kinerja. Jakarta: PT Bumi Aksara.

Siagian, S. P. (2002). Kiat Meningkatkan Produktivitas Kerja. Jakarta: Asdi Mahasatya. 
Wibowo. (2012). Manajemen Kinerja. Edisi Ketiga. Jakarta: PT Raja Grafindo Persada. Wibowo. (2010). Manajemen Kinerja: Edisi 2. Jakarta: PT Raja Grafindo Persada.

Wirawan. (2009). Evaluasi Kinerja Sumber Daya Manusia Teori, Aplikasi, dan Penelitian. Jakarta: Salemba Empat. 